\title{
Notes on Hume's Views in German Material Ethics of Values (From the History of Material Ethics of Values)*
}

DOI: http://dx.doi.org/10.12775/RF.2019.059

Material ethics of values was created in German philosophy, mainly through ideas introduced by Max Scheler in his groundbreaking work, Der Formalismus in Ethik und die materiale Wertethik (1913-1916). ${ }^{1}$ The ideas developed by Scheler had their heralds and harbingers in the past. But there were also some ideas in the background which were significantly different even though they ostensibly shared some theoretical similarity.

The aim of this study are relations existing between ideas developed in material ethics of values and ethical views espoused by David Hume. The problem under analysis encompasses two issues. The first issue has a reconstructive character as it is designed to extract from the writings of phenomenologists some references or passages relating to Hume's views. The second issue has a systematic character: the point here is to evaluate tentatively the validity of arguments advanced by individual philosophers. These two issues are not to be dealt with separately. The answer to the second question presupposes that the first question has been fully clarified. The problem of the relation between the views expounded by material ethicists of values and the modern concepts was

* Translated by Adam Gailewicz.

1 Max Scheler, Der Formalismus in der Ethik und die materiale Wertethik. Neuer Versuch der Grundlegung eines ethischen Personalismus, 4 durchgesehene Auflage, Gesammelte Werke, vol. 2, ed. M. [Maria] Scheler (Bern: Francke Verlag, 1954). 
investigated by me in various studies in which I made a positive and critical assessment of such philosophers as John Locke, Thomas Hobbes, Gottfried Wilhelm Leibniz, Immanuel Kant, Arthur Schopenhauer and Blaise Pascal. This study is a continuation of that research.

Why Hume? If the question involved relations or references to Pascal's thoughts, clarification would be easy to provide. ${ }^{2}$ The emotionalism

${ }^{2}$ I wrote about the relation between material ethics and Pascal in my article "Pascala droga serca a emocjonalne poznanie wartości w etyce materialnej (M. Scheler D. v. Hildebrand)", in: Zbigniew Drozdowicz (ed.), Spotkania z filozofia XVII wieku i jej kontynuacjami (Poznań: Fundacja Humaniora, 2009), 137-148. The conclusions made in that article may need to be supplemented with comments on the importance of Pascal's philosophy in the views of Nicolai Hartmann, Johannes Hessen and Hans Reiner. In Hartmann's Ethik, references to Pascal are twofold, and they are consequently investigated wherever a priori sense of values and response to values are discussed; Nicolai Hartmann, Ethik, 4 unveränderte Auflage (Berlin: Walter de Gruyter \& Co., 1962), 116, 389. At one point Hartmann gives a quote from Scheler's Der Formalismus in der Ethik: "There is something like a priori ordre du coeur, or logique du coeur, as Pascal rightfully says" (Ethik, 116, in Der Formalismus... the text is on page 84 ). Again when he maintains that the ordre du coeur reveals (prelusively) the order of values, i.e. their magnitude or fundamental or non-fundamental character (Ethik, 389). Noticeably, Hartmann's references to Pascal are in a manner of speaking inserted on a second-hand basis wherever Scheler's or Hildebrand's views are reconstructed or directly referred to. In his recently published book (Material Ehics of Values. Max Scheler and Nicolai Hartmann) Eugene Kelly mentions Pascal once and that in the context of Scheler's views; Eugene Kelly, Material Ethics of Values. Max Scheler and Nicolai Hartmann (Springer, 2011), 134. Diverse historical and philosophical deliberations are presented in the writings of Johannes Hessen (1889-1971) who repeatedly and explicitly refers in his views to classical representatives of material ethics (i.e. Scheler, Hartmann and Hildebrand). Wherever he examines Scheler's views, he points to his continuation of Pascal's core thought; likewise, the importance of Pascal's view to the intuitive and emotional thinking (St. Augustine, Hugo and Richard of St. Victor, Malebranche, Pascal, Shaftesbury, Hutcheson, Fries, Schleiermacher, Lotze, Dilthey, M. Frischeisen-Köhler, Franz Brentano, Scheler, Hartmann); Johannes Hessen, Wertphilosophie (Padeborn: Ferdinand Schöningh, 1937), 94, 114-115. On page 119, you can read that: "Brentano's research work is the continuation of the line of thought which leads from Pascal through English ethics to Lotze". Hessen also shows Pascal as a champion of the anthropological thesis acknowledging that man is a being which transcends itself, and asserts that the same view is held by Max Scheler (ibidem, 224). Lastly, one more case of this sort may be identified in Hans Reiner's texts. On the one hand, it is striking that in his textbook, Die philosophische Ethik, Chap. 4, where important theories of the existence and nature of the human "moral organ" are advanced, Pascal's name is not adverted to at all; however, multiple mentions are made of the views of Thomas Aquinas, Aristotle, Isocrates, Shaftesbury, Hutcheson, Hume, Adam Smith, Kant, J. Fr. Herbart, Hermann Lotze, Max Scheler, Nicolai Hartmann, Dietrich von Hildebrand and Reiner himself; Hans Reiner, Die philosophische Ethik. Ihre Fragen und Lehren in Geschichte und Gegenwart (Heidelberg: Quelle \& Meyer, 1964), 128-140. On the other hand, a different diagnosis arises from the examination of his other works. In Pflicht und Neigung, and then in Die Grundlagen der Sittlichkeit Pascal is referenced twice; needless to say, he is mentioned as the creator of the idea 
expressed in Pascal's idea of the Way of the Heart, in the notion of the reasons of the heart or, lastly, in the logic of the heart, finds its equivalent expression in specific categories of material ethics such as the feeling or experience of a value (Wertfühlen - Scheler), a sense of value (Wertgefühl - Hartmann, Reiner, Hessen), responding to values, being moved by values, discerning values, intuiting values (Dietrich von Hildebrand), even though they have never made material ethicists commit to any emotionalist declarations, because for them Pascal has always been the apple of their eye; because, in point of fact, they made references to Pascal on a derivative basis, whereas the core content of the axiological and moral experience upon which they founded their theories was in the foreground even at the very inception of their conceptual philosophical designs.

The relationship between material ethics of values and Kant's views should not be seen as surprising because Kant's position was a point of reference for this ethics, both a critical and a positive one. Needless to say, the main idea of material ethics was levelled at Kant's formalism.

Hume's case is different and definitely inexplicit. It is especially so because of the writings of individual representatives of material ethics in which references to Hume's views are very unevenly distributed. Remarkably, they are predominant in Hans Reiner's theories. Nevertheless, there is a very important reason that such a poor emergence of Hume's "keynotes" is equivalued in material ethics whereby it warrants my investigation: a growing trend of material ethics has led to the emergence of attempts to combine its distinctive aspects with some utilitarian, analytical or "empiricist" components. Such attempts were made by Reiner in his deliberations. Another fact is equally important. Looking at the 20th-century and most recent ethical concepts prevalent in the English speaking world (although many instances of this type are also found in Germany), we are surprised to find that references to Hume's views are quite regular and common and references to Max Scheler, Nicolai Hartmann, Dietrich von Hildebrand are extremely rare, while Johannes Hessen or Hans Reiner are almost anonymous. Therefore, it seems necessary to determine the relation of material ethics to Hume, the more so that the so-called emotionalist traits of Hume's ethics had their counterpart in the distinctive conceptions of intuiting values associated with material ethics. At this point, a question arises about the relation between these "emotionalisms". It is also necessary to explore this "emotionalist" issue because this emotionalism is more often than not an object of reproach and criticism. And finally, one more thing that matters here:

of reasons of the heart and the thesis of its "logic"; Hans Reiner, Die Grundlagen der Sittlichkeit. Zweite, durchgesehene und stark erweiterte Auflage von Pflicht und Neigung (Meisenheim am Glan: Verlag Anton Hain, 1974), 136, 173. 
in the literature known to me, this problem - material ethics of values and David Hume's views - has only several times been examined. ${ }^{3}$ There is no denying that at least a few common "keynotes" could be identified in Hume and phenomenological ethicists:

1) the role of emotional experiences in creating ethical and axiological awareness;

2) the differentiation of emotional experiences (in Hume it is described more specifically in A Treatise of Human Nature, but also in An Enquiry Concerning the Principles of Moral);

3) the dependence of reason in relation to feelings - described in detail, though differently;

4) the idea of cooperation (albeit with different roles), between reason and feelings. ${ }^{4}$

${ }^{3}$ Cf. Hanna Buczyńska-Garewicz, Uczucia i rozum w świetle wartości. Z historii filozofii wartości (Wrocław: Ossolineum, 1975); Marek Pyka, O uczuciach, wartościach i sympatii. David Hume, Max Scheler (Kraków: Universitas, 1999). Cf. also: Marek Pyka, On Emotion and Value in David Hume and Max Scheler, https:// www.bu.edu/wcp/Papers/Valu/ValuPyka.htm (accessed November 1, 2019): “On the other hand, their theories of emotion have also something in common. Firstly, both of them can be classified as 'normative' theories of emotion which means that they are developed as much to explain the nature of valuation as the nature of emotion. Secondly, and what is more important, both Hume and Scheler share a fundamental assumption concerning emotion; namely, that there is an original order between human emotions, on the one hand, and the realm of the good and values, on the other. At this point their positions contrast sharply with that of subjectivists and emotivists. One can risk here the statement, that a similar mutual correlation between the idea of emotion and the idea of the good (or value) could be found in any ethical theory which is based on emotion. Should we have an absolute theory of emotion, we could decide which of these ethical theories is right. There is a hope, however, that further research on emotion will throw some new light on the problem."

${ }^{4}$ David Hume, An Enquiry Concerning Principles of Morals, edited, and with an introduction, by J. B. Schneewind (Indianapolis, Cambridge: Hackett Publishing Company, 1983), 15: "These arguments on each side (and many more might be produced) are so plausible, that I am apt to suspect, they may, the one as well as the other, be solid and satisfactory, and that reason and sentiment concur in almost all moral determinations and conclusions. The final sentence, it is probable, which pronounces characters and actions amiable or odious, praise-worthy or blameable; that which stamps on them the mark of honour or infamy, approbation or censure; that which renders morality an active principle, and constitutes virtue our happiness, and vice our misery: It is probable, I say, that this final sentence depends on some internal sense or feeling, which nature has made universal in the whole species. For what else can have an influence of this nature? But in order to pave the way for such a sentiment, and give a proper discernment of its object, it is often necessary, we find, that much reasoning should precede, that nice distinctions be made, just conclusions drawn, distant comparisons formed, complicated relations examined, and general facts fixed and ascertained." Cf. also: Adam Grzeliński, "Ludzki rozum i afektywność - stanowiska Johna Locke'a i Davida Hume'a", Kultura i Wartości 2019, Nr 27: 30-33, DOI: http:// dx.doi.org/10.17951/kw.2019.27.17-35. 
Hume is cited in Max Scheler's ethics, but mainly as an example of Scheler's much criticized associationist concept of sympathy. ${ }^{5} \mathrm{~A}$ dozen references to Hume in Der Formalismus in der Ethik have no direct significance for the problem of moral sentiments. Hume is also cited in Das Ressentiment im Aufbau der Moralen wherever ressentiment and modern humanitarism are discussed, as one of the examples of those "great Englishmen" who "gradually formulated the theory of that ethos" and "tried to explain love as phenomena of sympathy, suffering and mutual joy, but these phenomena, in turn, are explained as a 'contagion'. [...] "what would you feel if it happened to you?"'. ${ }^{6}$

At the same time, in Hartmann's Ethik Hume's views are not mentioned at all! The situation is not much different as regards von Hildebrand's Ethik, for Hume is cited there only once, and that in the context unrelated to ethical issues, which represented a viewpoint disagreeable to Hildebrand. ${ }^{7}$ Hildebrand refers to Hume as a proponent of the perception of direct experience that would later be called positivistic. Such a perception of experience basically deviates from phenomenological experience because it fails to embrace generalities (i.e. it does not include the so-called phenomenological Wesenheiten). ${ }^{8}$

Hans Reiner was one of the material ethicists who wrote about Hume's views most copiously, in the context of moral sentiments. This problem is discussed in the textbook Die philosophische Ethik. ${ }^{9}$ Hume and his views are not cited in Reiner's principal work, in the treatise Pflicht und Neigung (republished under the title Die Grundlagen der Sittlichkeit). But it is Die philosophische Ethik where one can discover that Reiner not only references Hume's viewpoint as an element of history of ethics but detects an affinity between views expressed by material ethicists and Hume. It must also be emphasized that it is compatible with that version of material ethics which Reiner plied himself. It is therefore worthwhile to look more closely at the contexts where referents to Hume are identified in Reiner's writings. The following are the most important and need to be investigated.

${ }^{5}$ Cf. Max Scheler, Wesen und Formen der Sympathie (Bonn: Verlag von Friedrich Cohen, 1923), 274.

${ }^{6}$ Max Scheler, Das Ressentiment im Aufbau der Moralen (Frankfurt am Main: Klostermann Vittorio, 1978), 64.

7 Cf. Dietrich von Hildebrand, Ethik, 2. Auflage, Gesammelte Werke, Bd. 2 (Stuttgart: Verlag W. Kohlhammer, 1973), 16.

${ }^{8}$ Cf. in this case, especially the classic arguments against the positivistically understood experience formulated by Husserl. Cf. Edmund Husserl, Ideen zu einer reinen Phänomenologie und phänomenologischen Philosophie: Allgemeine Einführung in die reine Phänomenologie (Tübingen: Max Niemeyer Verlag, 2002), 41-45.

${ }_{9}$ Cf. Reiner, Die philosophische Ethik, 128-129, 134-135. 
Firstly, Hume's viewpoint is regarded by Reiner as an instance of a specific form of eudaemonism, i.e. such as is construed as a fundamental of morality (Sittlichkeitsbegründung). According to Reiner, other possible variants of eudaemonism are 1) eudaemonism as a general theory about the principle on which every human action relies, 2) eudaemonism as an ethical theory that maintains that happiness is the highest good and reflects on the pathways that lead to it.

These different variants may interconnect or exist separately. In Plato's views, for example, we can, according to Hume, identify all those variants whereas in Hume's views there is only one. Eudaemonism is understood here as a form of ethics which (in order to vindicate a position that an act is good) asserts that this act is good because it leads to active happiness. ${ }^{10}$

Secondly, Hume's viewpoint presented in An Inquiry Concerning the Principles of Morals, is evoked by Reiner as an important stage in the development of a view that moral feelings and reason are two different faculties of moral judgement, operating separately, but also jointly. In Reiner's opinion, Hume was the first to raise, in explicit terms, two complex questions concerning the role feelings play in the interpretation of good and evil. In order to justify that approach, Reiner first quotes a famous passage from the Inquiry:

There has been a controversy started of late $[\ldots]$ concerning the general foundation of moral: whether they be derived from reason or from sentiment; whether we attain the knowledge of them by a chain of argument and induction or by an immediate feeling and finer internal sense. ${ }^{11}$

What seems to be more important at this point is that Reiner emphasizes that Hume does not adopt a unilateral position but seeks for a method which would reconcile reason and feelings (sentiments), but in such a way which would retain their different functions and powers. The feeling of sympathy only expresses our approval or disapproval. It is reason that determines what is essentially useful or harmful. "This way Hume achieved an essential synthesis of rationalistic and emotional theory of moral cognition." ${ }^{12}$ Such a synthesis which accentuates different roles of feeling and reason leads to two clinching conclusions: 1) knowledge of good is neither purely rational nor purely emotional (emotionalistic); 2) the fundamental role goes to feelings (sentiments). ${ }^{13}$

10 Cf. ibidem, 47.

11 Cf. ibidem, 129 [Hume, An Enquiry Concerning the Principles of Morals, 13].

12 Ibidem, 134.

${ }^{13}$ Cf. ibidem. 
Thirdly, Reiner explicitly refers to Hume when he indicates that the division into the moral and the correct is an improvement upon and the accurate explication of Hume's division into a role of feelings (sentiments) and of reason in morality:

In addition to the existing difference between good and evil, Hume established a new difference, that between the morally right and the wrong. [...] Thus Reiner's idea of feeling [sentiment] and reason working apart and together has re-emerged in a new form. ${ }^{14}$

Action is moral whenever it realizes "objective" values. "Objective" values may be of different rank (e.g. less or more fundamental values or inferior or superior values); therefore, action may be "correct" whenever it realizes a more fundamental value and not a less fundamental one; when it realizes the superior value rather than the inferior one. Reiner has established eleven criteria to determine the hierarchy of values, but only one has an emotionalistic character. Consequently, Reiner may regard the division into the correct and the emotional as one that relates to Hume's division into the rational and the emotional.

There is a clear-cut division between the prominent representatives of the German material ethics. On the one side, there are Scheler, Hartmann, von Hildebrand, who discount the importance of Hume or tend not to write about Hume, or hardly write about him, but who underline the importance of Pascal. It must be borne in mind that the appreciation of Pascal is not equally shared by all those thinkers. Pascal is much treasured by Scheler, but Hartmann's attitude to him is rather enigmatic, which must be brought into focus in the context of reconstruction of Scheler's views. References to Pascal are present in Hildebrand's writings, though not as replete as in Scheler. This uneven distribution of interest in Pascal's views is effected by the fact Scheler and von Hildebrand addressed the issue of discernment and recognition of values in their individual ways. This issue was not emphasized in Hartmann who simply made use of solutions worked out by Scheler and Hildebrand. This conclusion will become more evident if we juxtapose and compare certain facts: Hartmann's Ethik contains eight hundred pages, but Hartmann devoted only twenty pages to appreciation of values. By comparison, Reiner, who investigates Pascal's importance by standard methods, underlines the role and value of views expounded by Hume in a manner unprecedented in material ethics.

14 Ibidem, 139: “Zunächst nämlich hat Reiner neben den Unterschied von Gut und Böse den anderen Unterschied zwischen sittlich Richtigen und Falschen gestellt. [...] Damit ist Humes Gedanke eines Nebeneinander- und Zusammenwirkens von Gefühl und Vernunft in neuer Form wieder aktuell geworden." 
This fact will be easily understood if you inquire into Reiner's specific viewpoint and the nature of modifications introduced by him as referred to in the text we have quoted above. In some earlier texts, I have already expressed a view that, in its historical development, the ethics of values originated from Scheler's viewpoint, where the role of the irrational-emotional nature of appreciation of values is emphasized most emphatically: and just as Pascal believes that moral good is perceived by the heart, so Scheler puts forward the view that emotional experiences where values are experienced in a way pointing to their source are the only appropriate way of appreciating values. They are not acts of learning about values (cognition is not of a source nature) but acts of experiencing values.

Reiner, in turn, proposes that rational factors should be seen as the more substantial contributors to learning about values. He thinks that phenomenological ethics may thus be protected against the reproach that views developed by its representatives, as founded in emotional intuition, are non-intersubjective and cannot be used as an argument in moral and axiological discourse, especially in its socio-cultural dimension. That is why much more than his predecessors, Reiner is interested in Hume's empiricist ethics. Such a shift towards what goes beyond emotional intuition can be seen in Reiner's concept of his typology of duty ${ }^{15}$ as well as in his idea of the need to reconcile the phenomenological perspective with the perspectives offered by the analytical ethicists. ${ }^{16}$

What Reiner treasures in Hume's moral theory is, first and foremost, the idea of cooperation between feelings (sentiments) and reason in the creation of moral consciousness. Only feelings can intimate that something is right or wrong, arousing approval or disapproval. Reason is only an instrument that shows how to achieve what is approved and avoid what is not approved. Approval or disapproval are shown in affects (direct or indirect). Reason has no motivating function; what matters are affects. Hume writes as follows:

Utility is only a tendency to a certain end; and were the end totally indifferent to us, we should feel the same indifference towards the means. It is requisite a sentiment sentiment should here display itself, in order to give a preference to the useful above the pernicious tendencies. This sentiment can be no other than a feeling for the happiness of mankind, and a resentment of their misery; since these are the different ends which virtue and vice have a tendency to promote. Here therefore reason instructs us in the

15 Cf. Hans Reiner, “Wertethik nicht mehr aktuell?”, Zeitschrift für philosophische Forschung 30, Bd. 1 (1976): 93-98.

${ }^{16}$ Cf. idem, Die philosophische Ethik, 168-176. 
several tendencies of actions, and humanity makes a distinction in favour of those which are useful and beneficial. ${ }^{17}$

In his article Begründungsformen der Ethik, Arno Anzenbacher summarizes the features of Hume's ethics in the following words:

In this way Hume explains morality - both its content and its motivation - only through the structure of sensory affects [...]. Hume represents definitely the empiricist morality of feelings. Reason [...] does not motivate but, in practice, performs solely an instrumental role. The objectives, the motives or the content of practice emerge (as motivated by pleasure and displeasure) from affects, feelings and inclinations, while reason only indicates the means necessary to accomplish the goals. ${ }^{18}$

Reiner appreciates Hume's position but emphasizes that it was not until the formation of material ethics of values that Hume's fallacies were eliminated. Although he does not specify or identify the fallacies, they can be inferred or deduced by means of the appreciation Reiner considers to be correct. Clearly, it is the approach proposed by material ethics of values, in particular the approach proposed by Reiner himself.

Hume's "fallacies", as it were, are his failure to discern that there must be something in the behaviour itself, in acting or taking action, that motivates a specific emotional experience. At this point, material ethics introduces the concept of value. From this perspective, I think Reiner could say that his own proposition is most consistent with the direction set by Hume, because he defines a positive value as that which pleases us, and a negative value as that which does not please us. In this way, Reiner may think that his understanding of values is the least speculative, and the most "empirical", so to speak, as seen in comparison with such understanding as proposed by other earlier phenomenologists. The most empirical, because it applies to experience a person (subject) is undergoing.

17 Hume, An Enquiry Concerning Principles of Moral, 83 (Appendix 1. Concerning Moral Sentiment).

18 "Auf diese Weise erklärt Hume die Moral sowohl hinsichtlich ihres Inhalts als auch ihrer Motivation ausschließlich durch ein Gefüge sinnlicher Affekte [...]. Er vertritt insofern eine ausgeprägt empiristische Gefühlsmoral. Die Vernunft (reason) als solche, die Hume (im ersten Buch der Treatise) aus der kognitiven Sinnlichkeit rekonstruiert, motiviert nicht, sondern spielt in der Praxis nur eine instrumentelle Rolle. Die Ziele, Motive bzw. Inhalte der Praxis ergeben sich im Sinne der Lust-Unlust-Motivation aus den Affekten, Gefühlen und Neigungen, während die Vernunft lediglich die zur Verwirklichung der Ziele erforderlichen Mittel aufweist"; Arno Anzenbacher, „Begründungsformen der Ethik”, Kultura $i$ Wartości 8 (2013): 1541. DOI: http://dx.doi.org/10.17951/kw.2013.8.15 
However, is Reiner's interpretation tenable? Yes and no. Yes, because there are no other determinants of values in Reiner's texts. No, because Reiner states in one of his texts that his intention is to develop not only a phenomenology of values (to show how they manifest themselves, how they are experienced by a subject), but also to develop a metaphysics of value and freedom. Metaphysics, on the other hand, would have to explain how it is possible there is something that arouses joy or disapproval. Although Reiner had never realized this idea, his intention still remains to be fulfilled. Yet, the intention is inconsistent with that point of departure, i.e. Hume's viewpoint.

This is a partial answer to the question to what extent and how effectively Reiner's reinterpretation of Hume's idea has overcome their shortcomings. I have already written elsewhere about difficulties connected with Hume's views. ${ }^{19}$ Let me reiterate them below:

1) Hume's ethics leads to reason being assigned an instrumental role only;

2 ) it equates values with axiological experience, which means it may be reproached as an appeal to nature;

3) it does not propose a division of feelings into different types (physical, spiritual, psychological), although at the same time one cannot escape the importance of the proposed "material" classifications of feelings, detailed, broad and meticulous.

With respect to the first point, the solutions proposed by Reiner diversify the role of reason because, in nine cases out of ten, it is the rationale of reason that determines if one should assume or abandon a duty. Things are different as regards the second issue. By defining value as what pleases us, Reiner defies the possibility of subjectifying values, but does not effectively avoid the reproach of committing a fallacy of appeal to nature. If, for example, what pleases you is your child's success in school, then the problem is twofold. On the one hand, there is no more precise definition of what is the position of values in the structure of a particular event that is happening to you. On the other hand, the joy, if treated as a value characteristic, will have to share the doom of pleasure George Edward Moore wrote about when interpreting hedonism as an example of a viewpoint vitiated by an appeal to nature.

The listed shortcomings do not, however, eliminate the value of a possible synthesis of emotionalism and intellectualism. Such a synthesis may be a good point of departure to detect how to esteem or appreciate values accurately. It may also be used as an effective safeguard against one of the forms of relativism, the one which insists that the emotional

${ }^{19}$ Cf. Leszek Kopciuch, "Nowożytne koncepcje wartości”, in: Metafizyka, vol. 2, ed. Stanisław Janeczek, Anna Starościc (Lublin: Wydawnictwo KUL), 391-393. 
appreciation of values - due to its diversity - must lead to a relativistic position. It can also form the basis for a social consensus likely to result from rational discourse and weighting of reasons.

\section{Bibliography}

Anzenbacher Arno. 2013. "Begründungsformen der Ethik", Kultura $i$ Wartości 8: 15-41. DOI: http://dx.doi.org/10.17951/kw.2013.8.15

Buczyńska-Garewicz Hanna. 1975. Uczucia i rozum w świetle wartości. Z historii filozofii wartości. Wrocław: Ossolineum.

Grzeliński Adam. 2019. "Ludzki rozum i afektywność - stanowiska Johna Locke'a i Davida Hume'a." Kultura i Wartości 27: 17-35. DOI: http://dx.doi.org/10.17951/kw.2019.27.17-35

Hartmann Nicolai. 1962. Ethik, 4. unveränderte Aufl. Berlin: Walter de Gruyter \& Co.

Hessen Johannes. 1937. Wertphilosophie. Padeborn: Ferdinand Schöningh.

Hildebrand Dietrich von. 1973. Ethik, 2. Auflage, Gesammelte Werke, Bd. 2. Stuttgart: Verlag W. Kohlhammer.

Hume David. 1983. An Enquiry Concerning Principles of Moral, edited, and with an introduction, by J. B. Schneewind. Indianapolis, Cambridge: Hackett Publishing Company.

Husserl Edmund. 2002. Ideen zu einer reinen Phänomenologie und phänomenologischen Philosophie: Allgemeine Einführung in die reine Phänomenologie. Tübingen: Max Niemeyer Verlag.

Kelly Eugene. 2011. Material Ethics of Values. Max Scheler and Nicolai Hartmann. Springer.

Kopciuch Leszek. 2009. "Pascala droga serca a emocjonalne poznanie wartości w etyce materialnej (M. Scheler - D. v. Hildebrand)". In: Spotkania z filozofia XVII wieku i jej kontynuacjami, ed. Zbigniew Drozdowicz. 137-148. Poznań: Fundacja Humaniora.

Kopciuch Leszek. 2017. "Nowożytne koncepcje wartości". In: Metafizyka, vol. 2, ed. Stanisław Janeczek, Anna Starościc. 387-417. Lublin: Wydawnictwo KUL.

Pyka Marek. 1999. O uczuciach, wartościach i sympatii. David Hume, Max Scheler. Kraków: Universitas.

Pyka Marek. On Emotion and Value in David Hume and Max Scheler, https://www.bu.edu/wcp/Papers/Valu/ValuPyka.htm (accessed November 1, 2019).

Reiner Hans. 1964. Die philosophische Ethik. Ihre Fragen und Lehren in Geschichte und Gegenwart. Heidelber: Quelle \& Meyer.

Reiner Hans. 1974. Die Grundlagen der Sittlichkeit. Zweite, durchgesehene und stark erweiterte Auflage von Pflicht und Neigung. Meisenheim am Glan: Verlag Anton Hain.

Reiner Hans. 1976. “Wertethik nicht mehr aktuell?”. Zeitschrift für philosophische Forschung 30, Bd. 1: 93-98. 
Scheler Max. 1954. Der Formalismus in der Ethik und die materiale Wertethik. Neuer Versuch der Grundlegung eines ethischen Personalismus, 4. durchgesehene Auflage, Gesammelte Werke, Bd. 2, ed. Maria Scheler. Bern: Francke Verlag.

Scheler Max. 1978. Das Ressentiment im Aufbau der Moralen. Frankfurt am Main: Klostermann Vittorio.

Scheler Max. 1923. Wesen und Formen der Sympathie. Bonn: Verlag von Friedrich Cohen.

\section{Summary}

The subject of this study are relations between ideas developed in material ethics of values and ethical views formulated by David Hume. The problem under analysis encompasses two issues. The first issue has a reconstructive character, as it is designed to extract from the writings of phenomenologists some references or passages relating to Hume's views. The second issue has a systematic character: the point here is to evaluate tentatively the validity of arguments advanced by individual philosophers.

Keywords: material ethics of values, David Hume, Max Scheler, Nicolai Hartmann, Dietrich von Hildebrand, Hans Reiner 